DOI https://doi.org/10.18551/rjoas.2018-11.37

\title{
MULTIDIMENSION ASSESMENT OF OIL PALM SUSTAINBILITY ON PEATLAND: A CASE STUDY OF OIL PALM SMALLHOLDER IN RUPAT, RIAU PROVINCE OF INDONESIA
}

\author{
Hidayat Herman* \\ Postgraduate School of Environmental and Development, University of Brawijaya, \\ Malang, Indonesia
}

Soemarno

Department of Soil Science, Faculty of Agriculture, University of Brawijaya, Malang, Indonesia

Muhaimin Abdul Wahib

Department of Agriculture Economic, Faculty of Agriculture, University of Brawijaya, Malang, Indonesia

*E-mail: hhidayaat@yahoo.co.id

\begin{abstract}
This study aims to assess the sustainability index and status of smallholder oil palm plantations on peatlands. By using a multidimensional approach which was then analyzed using the Rap-SAWIT technique, modified from RAPFISH (Rapid Assessment Technique for Fisheries). It was found that the sustainability index value of smallholder palm oil plantations on peatland in Tanjung Kapal Village is $56.19 \%$ with fairly sustainable status. The results of the analysis of each dimension show that the institutional dimensions have the highest index value of $71.12 \%$ with a fairly sustainable status, then subsequently followed by the environmental dimension with an index value of $67.75 \%$ with a fairly sustainable status, an economic dimension with index value of $60.46 \%$ with a fairly sustainable status, technology and infrastructure dimension with index value of $48.13 \%$ with a fairly sustainable status and with the lowest index value of the social dimension has an index value of $33.50 \%$ with a less sustainable status. There are 20 key factors that affect the sustainability of smallholder oil palm plantations on peatlands.
\end{abstract}

\section{KEY WORDS}

Sustaibility, multidimension, rapfish, smallholder, oil palm, peatland.

As a tropical country, Indonesia has around 13.5-26.5 million ha of peatland (Wetland International, 1996). Peatland ecosystems can mostly be found on Sumatra ( 8.9 million ha), Kalimantan (6.5 million ha) and Papua (10.5 million ha). Peatlands have ecological, economic and social functions. As a store of carbon, peatland plays a role in the carbon cycle and serve as sponges which can absorb rainwater to reduce the impact of flooding. Peatlands can also be used as agricultural land.

In the Southeast Asian region, including Indonesia, peatlands are utilized for the development of agriculture and plantations due to the narrowing of agricultural land and increasing population. The most developed commodity in peatland is oil palm. An estimated 1.3 million ha of peatland in Indonesia is planted by oil palm (Page et al, 2011) and this number is predicted to increase to 2.5 million ha by 2020 (Hooijer et al, 2006; Page et al, 2011). Oil palm plantation is an important sector in regional development in Riau Province. The increasing demand for derivative products made from raw CPO (Crude Palm Oil) has caused wider land clearing for oil palm plantations.

Oil palm plantations are divided into three categories: Large Private Plantations, State Plantations and Smallholder Plantations. Hutabarat (2017) states that smallholder plantations have an important role in the development of oil palm plantations. The area of smallholder oil 
palm plantations reached $41.4 \%$ of the total area of Indonesian oil palm plantations with a production of $36.6 \%$ of the total Indonesian palm oil production in 2016 . With the total number of smallholder plantation farmers reaching 2.3 million, smallholder oil palm plantations are expected to be the driving force of the rural economy. However, smallholder plantation farmers face problems such as the lack of technology mastery, the lack of knowledge regarding peatland management and clearing by burning which causes damage to the peat ecosystem.

The use of peatlands for the development of oil palm plantations is thought to be the cause of environmental damage and the loss of economic and social functions on peatlands. A multidisciplinary approach that integrates ecological, social and economic aspects can evaluate the sustainability of plantation activities (Cooke et al, 2009; Walter and Stuzel, 2009). This study aims to assess the sustainability status of smallholder oil palm plantations on peatlands by integrating environmental, economic, social, technology infrastructure and institutional dimensions. The assessment of sustainability status of oil palm plantations is important to conduct in order to determine the right steps to ensure future sustainability.

\section{METHODS OF RESEARCH}

This research was conducted in Tanjung Kapal Village of Rupat District in Riau Province for 4 (four) months from May 2018 to August 2018. The location was chosen as it represents one of the central areas of smallholder oil palm plantations in Riau Province. The population of this research includes 631 smallholders who manage plantations on peatland. The sample of this study consists of $10 \%$ of the total population, particularly 63 oil palm farmers. Primary data collection is done by survey, questionnaire and independent interview. The questionnaire provided contains attributes of the five dimensions of sustainability from literature review of prior studies. The attributes in this study amounted to 36; each attribute is given a score of $0-3$, where ' 0 ' is very good and ' 3 ' is bad.

Data of the study were analyzed using Multidimensional Scaling approach with RapSAWIT technique modified from RAPFISH (Rapid Assessment Technique for Fisheries) developed by the Fisheries Centre of University of Columbia (Kavanagh, 2001). The RAPFISH application was run on an add-in of Microsoft Excel. The sustainability index scale is organized into four sustainability categories, namely: (1) $0.00-25.00$ represents bad sustainability status, (2) 25.01-50.00 indicates poor sustainability status, (3) 51.01-75.00 denotes fair sustainability status and (4) 75.01-100.00 indicates good sustainability status. The attributes of each dimension are analyzed using Leverage Analysis to determine the effect of each of the key factors of the five dimensions of sustainability. The index and sustainability status of each dimension is visualized in the form of a kite diagram. Monte Carlo analysis is done to determine the error rate on the attributes under study.

\section{RESULTS AND DISCUSSION}

Environmental Dimension. Sustainability analysis of environmental dimension is carried out using 8 (eight) attributes that are expected to affect sustainability, namely (1) land use; (2) land clearing; (3) biodiversity conservation; (4) water management arrangements; (5) frequency of flooding; (6) frequency of forest and land fires; (7) pest control and (8) use of chemical fertilizers. The results of the Multidimensional Scaling analysis on the environmental dimension show a sustainability index of $67.75 \%$ (Figure 1a). The key factors that affect the sustainability index in the environmental dimension are: (1) frequency of land fire; (2) pest control; (3) use of chemical fertilizers and (4) water management arrangements (Figure 1b). 


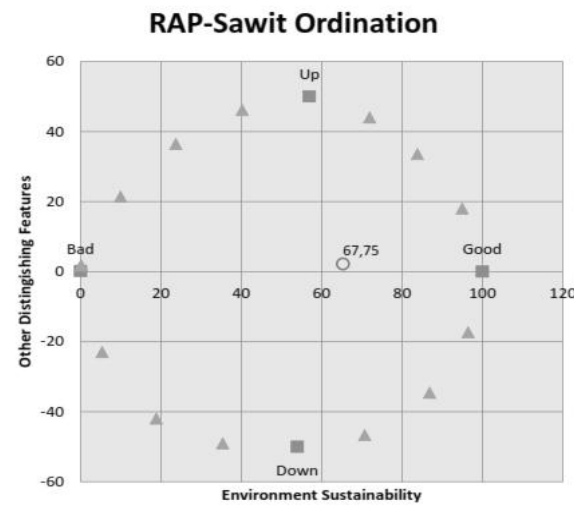

(a)

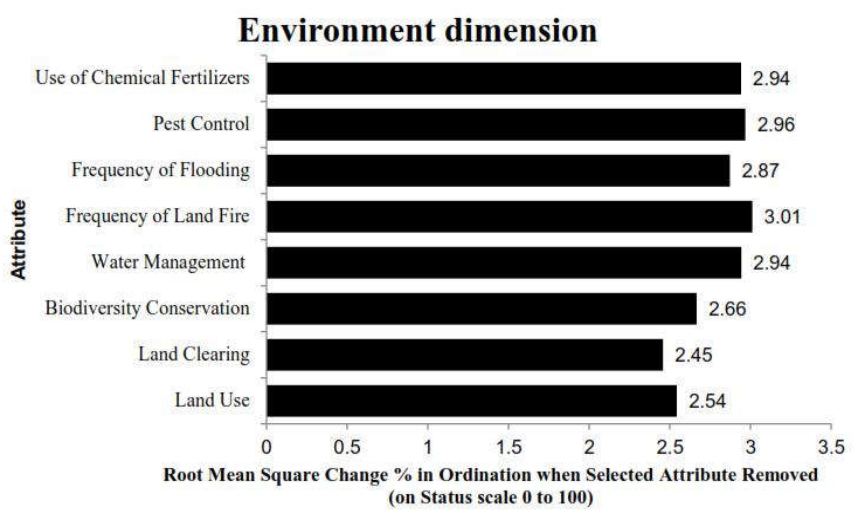

(b)

Figure 1 - Sustainability index (a) and sensitive attributes that affect environmental dimension (b) of smallholder oil palm plantations

Fertilization is one of the determining factors for achieving high productivity in oil palm plantation. Fertilization of oil palm must be done to guarantee vegetative and generative growth in order that oil palm can produce optimal fresh fruit bunches and produce quality palm oil (Adwignda, 2007). Peatland is an environment that has high potential for disease outbreaks (Noor, 2001). Pest attacks can reduce the production of fresh fruit bunches in the first year by up to $69 \%$ and death in young plants. The use of environmentally friendly fertilizers and integrated pest control can guarantee the sustainability of oil palm.

To reduce environmental risks and impacts, the utilization of peatlands is done selectively and very carefully. The water table arrangement will greatly affect the productivity of oil palm, the ideal condition of groundwater level must be maintained between $30-80 \mathrm{~cm}$. Groundwater level that is too shallow will cause oil palm growth to be disturbed whereas groundwater level that is too deep can cause a rapid rate of subsidence and cause dryness, therefore flammable. Fires on peatlands will be very difficult to extinguish because they can penetrate below the soil surface (Najiyati et al, 2005). The clearing of oil palm plantations with slash and burn system is the main trigger for forest fires on peatlands.

Economic Dimension. The sustainability analysis of the economic dimension was carried out using 8 (eight) attributes including (1) land area; (2) land ownership; (3) production costs; (4) total productivity; (5) total income; (6) total revenue contribution; (7) selling price, and (8) marketing (Figure 2a). The result of the MDS analysis for the sustainability index of the economic dimension is $60.46 \%$. The key factors that influence the sustainability of the economic dimension are: (1) selling prices; (2) production costs; (3) total income, and (4) total productivity (Figure $2 \mathrm{~b}$ ).

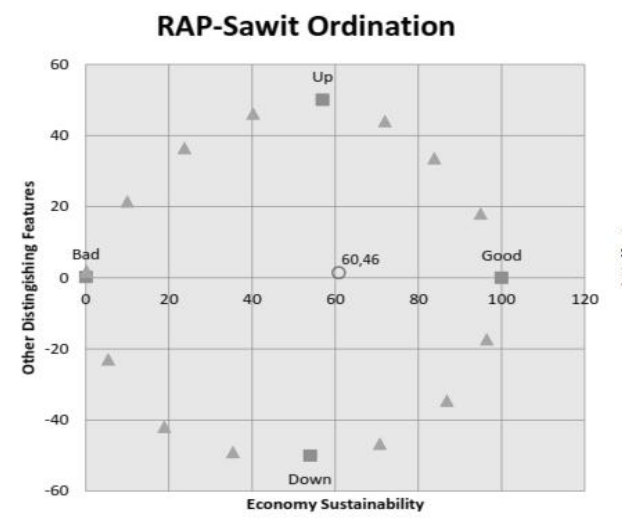

(a)

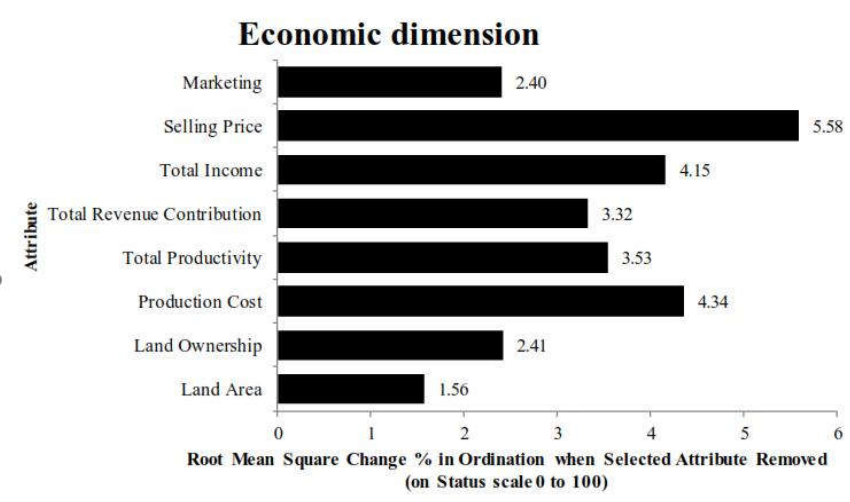

(b)

Figure 2 - Sustainability index (a) and sensitive attributes that affect economic dimension (b) of smallholder oil palm plantations 
The income of oil palm farmers depends on the age of the oil palm plantations, the older the oil palm plant (optimum age), the more the palm kernel. The high content of core palm oil produced will then affect the price of fresh fruit bunches received by farmers. On average, oil palm plants that are more than 25 years old will require replanting. The selling price received by farmers will affect the sustainability in managing oil palm farming. The average productivity of smallholder oil palm plantations in Riau Province is lower than private plantations.

The inequality in the number of producers is due to production inputs such as the use of fertilizers, seeds and the use of technology. On average, oil palm farmers produce 65.82 tons of year ${ }^{-1}$ on a land area of 2.1 ha. With an average selling price of fresh fruit bunches of Rp. $1,280 \mathrm{~kg}^{-1}$ farmer income in farming is Rp. 84,256.508 year ${ }^{-1}$ with a total income of Rp. $57,325.596$. Farming feasibility can be calculated using the formula of Revenue Cost Ratio $(\mathrm{R} / \mathrm{C})$ with $\mathrm{R} / \mathrm{C}$ value, it can be discovered whether a farm can be profitable or not. Farming is said to be feasible and can continue if $R / C>1$. The $R / C$ value of smallholder oil palm plantations managed by farmers is 2.13 , which means that oil palm farming is profitable.

Social Dimension. The sustainability analysis of social dimension is done using 6 (six) attributes, namely: (1) frequency of social conflict; (2) participation of family labor; (3) level of knowledge regarding sustainability; (4) management of peat based on local wisdom; (5) age of farmers, and (6) level of education of farmers. The result of the Multidimensional Scaling analysis for the sustainability index in the social dimension is $33.50 \%$ (Figure 3a). Key factors that influence social dimension include: (1) participation of family labor; (2) level of knowledge regarding sustainability; (3) age of farmers, and (4) frequency of social conflict (Figure 3b).

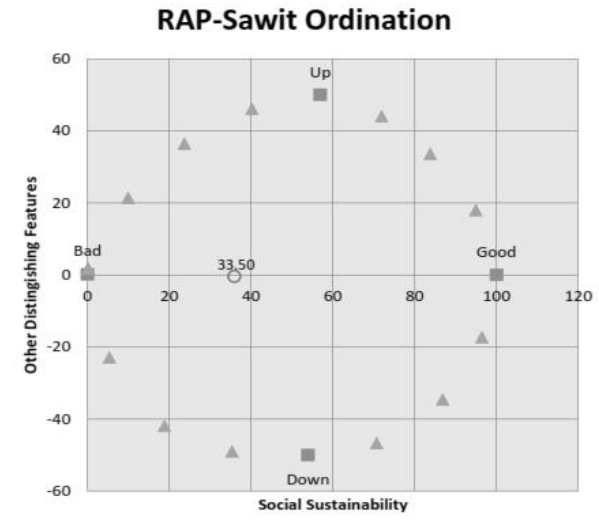

(a)

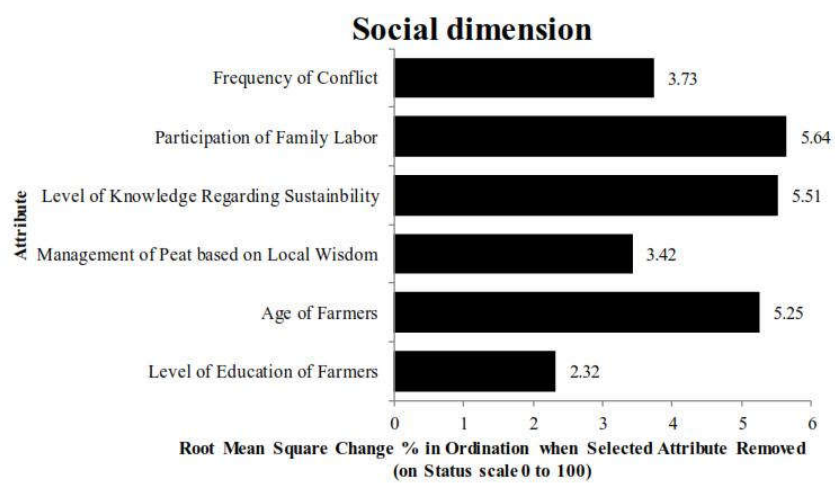

(b)

Figure 3 - Sustainability Index (a) and sensitive attributes that affect social dimension (b) of smallholder oil palm plantations

Social conflict problem in the development of oil palm plantations shows an increasing intensity. Social conflict usually occurs between local community and private companies based on unilateral claims on land management rights (Suwondo, 2011). The growing private plantation expansion activities tend to cause higher level of social conflict. In agrarian conflicts, local community is usually in defeated position as they do not have legal proof of land ownership. Sumardjo (2010) explains, the concept of social development and Corporate Social Responsibility (CSR) needs to be applied to overcome social conflicts between indigenous communities and private companies. In addition, partnerships between industry and farmers will create mutually beneficial cooperation and avoid social conflict.

Palm oil commodities that do not last long and which require advanced technology for processing need adequate quality of human resources. Therefore farmers who are still in productive age are needed. The age of farmers influences their work ability (Nurmedika, 2015). Younger farmers tend to have a working spirit and can accept innovation and take risks. The 2013 Agricultural Census Results Report explains that the productive age of 
farmers is 15-64 years. Farmers who exceed the productive age have a tendency to have low working spirit. The regeneration of farmers in managing oil palm plantations is key to the sustainability of oil palm farming.

Technology and Infrastructure Dimension. Sustainability analysis of technology and infrastructure dimension is carried out using 7 (seven) attributes, namely: (1) road condition; (2) transportation; (3) distance to processing plant; (4) fire prevention; (5) harvest technology; (6) land conservation, and water and (7) the use of quality seeds. Result of Multidimensional Scaling shows that the sustainability index within the technology and infrastructure dimension is $48.13 \%$ (Figure $4 a$ ). The key factors that influence the sustainability of the technology and infrastructure dimension includes: (1) road condition; (2) harvest technology; (3) land fire prevention, and (4) the use of quality seed (Figure $4 b$ ).

The success of harvesting activities also depends on the cultivation activities and the availability of infrastructure facilities for processing activities (Muhammad, 2015). Harvesting activities must pay attention to fruit maturity, crop rotation and fruit cutting aspects. In smallholder oil palm plantations, harvesting activities are carried out periodically 4 times a month.

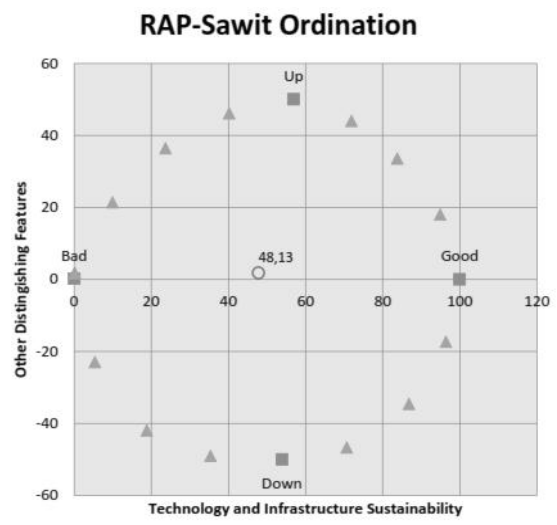

(a)

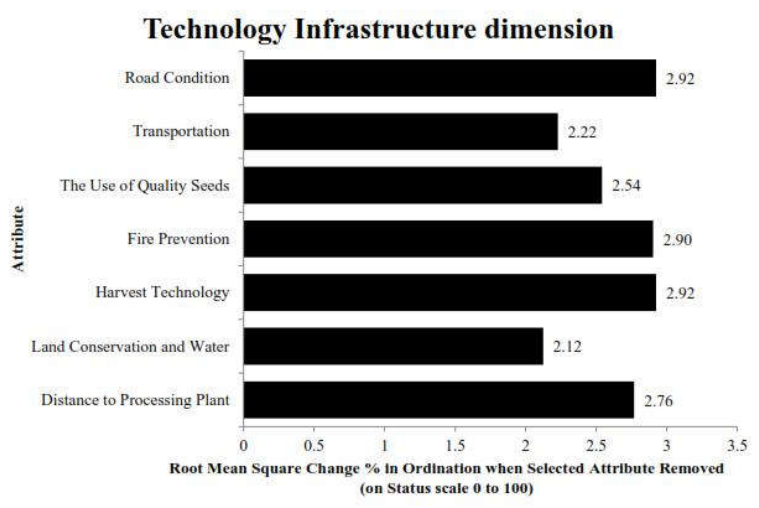

(b)

Figure 4 - Sustainability index (a) and sensitive attributes that affect dimensions of technology and infrastructure (b) in smallholder oil palm plantations

Infrastructure has an essential role as the driver of agricultural development. The smooth transportation of fruits depends on road conditions. Good connecting road conditions are key to the distribution of fresh fruit bunches to processing plants. After being harvested, fresh fruit bunches must be transported to the processing plant to avoid the presence of wet fatty acids (Sinarmas, 2017). The palm oil processing industry has an important role in maintaining the stability of the price of fresh fruit bunches produced by farmers. The characteristics of palm fruit (i.e., easily damaged and significant quality reduction) requires the availability of a processing industry that is not far from the location of the plantation.

Institutional Dimension. The institutional dimension of sustainability analysis is carried out using 7 (seven) attributes, namely: (1) government support; (2) policy of land clearing without burning; (3) farmer participation in farmer groups; (4) availability of farmer groups; (5) access to financial institutions; ( 6) availability of financial institutions, and (7) permits. The results of the Multidimensional Scaling reveal sustainability index on the institutional dimension is $71.12 \%$ (Figure $5 a$ ). The key factors influencing the institutional dimension are: (1) government support; (2) access to financial institutions; (3) policy on non-burning land clearing, and (4) participation of farmers in farmer groups (Figure $5 \mathrm{~b}$ ).

The government has attempted to prevent and reduce the negative impact of oil palm expansion by issuing a moratorium on granting business licenses for private companies to expand oil palm plantations on primary natural forests and peatlands. This policy was issued in Presidential Instruction (Inpres) No. 8 of 2015. In addition to preventing the negative impacts caused by oil palm plantations, the moratorium policy aims to encourage increased 
productivity of smallholder oil palm plantations (Suwondo, 2011). This opportunity to increase productivity put into consideration the fact that currently smallholder plantations only produce 16 tons of fresh fruit bunches year ${ }^{-1}$, while the production potential reaches 30 tons year ${ }^{-1}$ (BBP2TP, 2013).

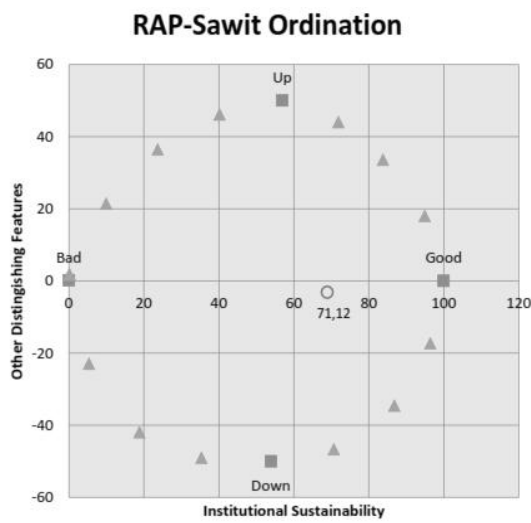

(a)

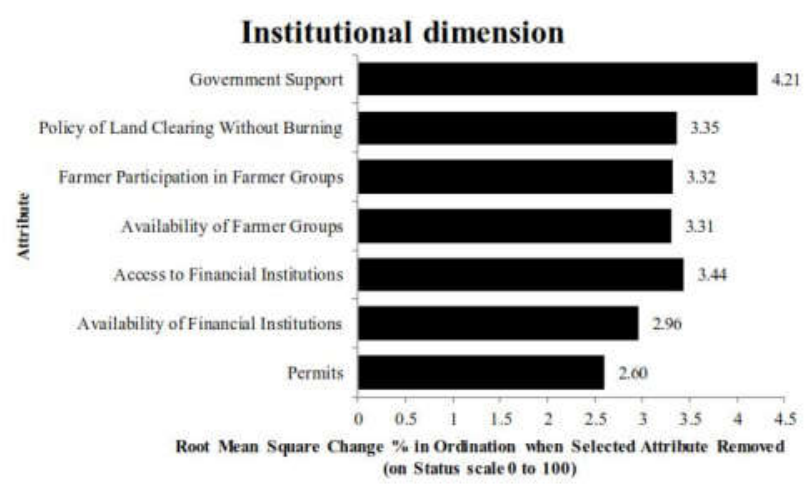

(b)

Figure 5 - Sustainability index (a) and sensitive attributes that affect the institutional dimension (b) in smallholder oil palm plantations

The commitment of the Regional Government through the Department of Agriculture can be seen from the routine provision of fertilizer subsidies and the provision of counseling on the development of oil palm plantations on peatlands. The Regional Government in the Regional Medium Term Plan (RPJMD) is working on the development of superior commodity processing industries to increase the added value of oil palm. Strong institutions will create independent rural communities. Syahza (2010) emphasizes the importance of economic institutions and farmer groups in reducing the gap between smallholder plantations and private plantations.

Sustainability Index and Status for each dimension. The results of the analysis using Rap-Sawit show that the value of the sustainability index on smallholder oil palm plantations on peatlands is categorized as fairly sustainable with an index value of $56.19 \%$. The sustainability index values of the Environmental dimension is 67.75 (fairly sustainable); Economic dimension is $60.46 \%$ (fairly sustainable), Social dimension is $35.50 \%$ (poorly sustainable), Technology infrastructure dimension is $48.13 \%$ (poorly sustainable) and Institutional dimension is $71.12 \%$ (fairly sustainable) ( Figure 6). To improve the sustainability status of oil palm plantations, it is necessary to improve social aspects by increasing farmers' knowledge of peatland management and improving supporting infrastructure that supports plantation activities.

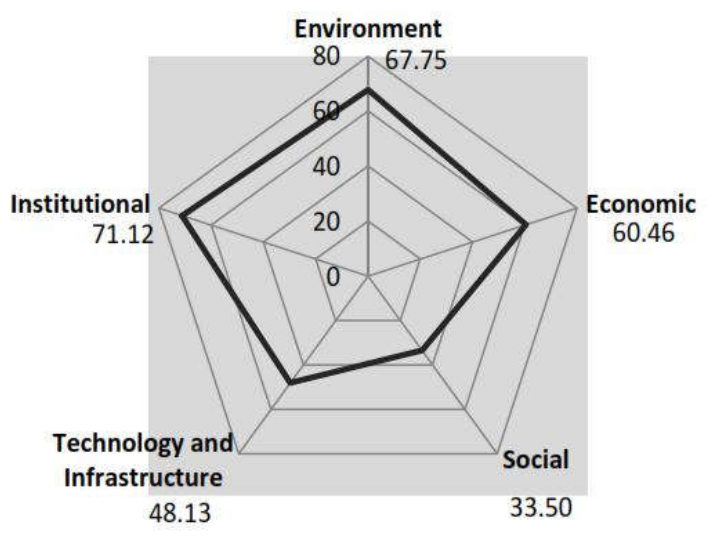

Figure 6 - Kite Diagram Sustainability Index of Smallholder Palm Oil Plantations on Peatlands 
Table1 - Difference in Values of Monte Carlo and Multidimensional Scaling

\begin{tabular}{cccc}
\hline \multirow{2}{*}{ Sustainability Dimensions } & \multicolumn{2}{c}{ Sustainability Index Value (\%) } & \multirow{2}{*}{$\begin{array}{c}\text { Difference between the values } \\
\text { of Monte Carlo and MDS }\end{array}$} \\
\cline { 2 - 3 } & MDS Value & Monte Carlo Value & 0.81 \\
Environment & 67.75 & 66.93 & 0.74 \\
Economic & 60.46 & 59.72 & 0.44 \\
Social & 33.50 & 33.06 & 0.09 \\
Technology and Infrastructure & 48.13 & 48.04 & 0.75 \\
Institutional & 71.12 & 70.36 & 0.75 \\
\hline
\end{tabular}

Table 1 displays the difference between the Multidimensional Scaling and Monte Carlo values. Monte Carlo analysis is done to find out errors in Rap-Sawit analysis. Monte Carlo analysis shows that at $95 \%$ confidence level, each dimension has a small difference. Based on the data obtained, the differences between values in each dimension is $<1$. It can be concluded that: (1) Rap-SAWIT has a relatively small error in providing scoring to each attribute; (2) has a high level of Multidimensional Scaling stability; (3) the attributes studied have a high level of confidence. Rap-SAWIT method is good enough as one of the tools in assessing the sustainability of smallholder oil palm plantations on peatlands.

\section{CONCLUSION}

The sustainability of smallholder oil palm plantations on peatlands has a sustainability index value of $56.19 \%$ with a fairly sustainable status. Leverage analysis in each dimension shows that social dimension is the dimension with the lowest sustainability index value $(33.50 \%)$ with poor sustainability status. Increasing the sustainability status of the social dimension can be done by preventing social conflict and improving the management of peatland based on local wisdom. Monte Carlo analysis shows that each attribute in the use of Rap-SAWIT is valid and can be accounted for, hence it can be used as a guide to evaluate the sustainability of smallholder oil palm plantations on peatlands.

\section{REFFERENCES}

1. Adiwiganda, R. (2007). Manajemen Tanah dan Pemupukan Kelapa Sawit. Di dalam: S. Mangoensoekarjo (ed). Manajemen Tanah dan Pemupukan Budidaya Tanaman Perkebunan. Gadjah Mada University Press, Yogyakarta.

2. BBP2TP. (2015). Teknologi Budidaya Kelapa Sawit. Badan Litbang Kementerian Pertanian. Bogor.

3. Cooke, I.R., et al. (2009). Integrating Socio-Economic and Ecology: Taxonomy of Quantitative Methods and a Review of Tropical Peat Research Laboratory and Applied Agriculture Resources. Kuala Lumput.

4. Hooijer, A., Silvius, M., Wosten, H., Page, S. (2006). PEAT-CO ${ }_{2}$, Assesment of $\mathrm{CO}_{2}$ Emissions from Drained Peatland in Southeast Asia. Delft Hydraulics report Q3943. WL Delft Hydraulics, Delf, Netherlands.

5. Hutabarat, S. (2017). Tantangan Keberlanjutan Perkebunan Kelapa Sawit Rakyat Di Kabupaten Pelalawan, Riau dalam Perubahan Perdagangan Global. Jurnal IImu Sosial Indonesia. 43 (1): 47-64.

6. Kavanagh, P. (2001). Rapid Appraisal of Fisheries (RAPFISH) Project. University of British Columbia, Fisheries Centre.

7. Muhammad. (2015). Kajian kegiatan Panen di Perkebunan Kelapa Sawit (Eagis Guineensis Jacq) PT. Sawit Sejahtera Desa Senyir Kecamatan Muara Ancalong Kabupaten Kutai Timur Provinsi Kalimantan Timur. Program Studi Budidaya Tanaman Perkebunan.

8. Najiyati, S., Agus Asmana, I Nyoman N. Suryadiputra. (2005). Pemberdayaan Masyarakat di Lahan Gambut. Proyek Climate Change, Forests and Peatlands in Indonesia. Wetlands International - Indonesia Programme dan Wildlife Habitat Canada. Bogor.

9. Noor, M. (2001). Pertanian Lahan Gambut; Potensi dan Kendala. Kanisius. 
10. Nurmedika. (2015). Analisis Faktor-Faktor Yang Mempengaruhi Pilihan Petani Meakukan Alih Usahatani di Kecamatan Rio Kabupaten Donggala. Jurnal Agroland. 22 (1): 61-66.

11. Page, S.E., Rieley, J.O., Banks, C.J. (2011). Global and Regional Importance of The Tropical Peatland Carbon pool. Global Change Biology. 17 (2): 798-818.

12. Sinarmas. (2017). Dari Kebun ke Pabrik dalam 24 Jam. From https://www.smarttbk.com/kebun-ke-pabrik-dalam-24-jam/

13. Sumardjo. (2010). Model Pemberdayaan Masyarakat dan Pengelolaan Konflik di Provinsi Riau. Pusat Kajian Resolusi Konflik (CARE) Lembaga Penelitian dan Pengabdian kepada Masyarakat Institut Pertanian Bogor.

14. Suwondo., Sabiham, S., Sumardjo., Parmudya, B. (2011). Analysis Of Sustainbility Peatland In Agroecology Oil Palm Plantation. Jurnal Rekayasa Lingkungan. 7 (2): 161 170.

15. Syahza, A. (2010). Model Kelembagaan Ekonomi pada Perkebunan Kelapa Sawit di Provinsi Riau. Seminar dan Lokakarya Pengelolaan terpadu Lingkungan Perkebunan Kelapa Sawit Berkelnjutan di Provinsi Riau. Pekanbaru.

16. Walter, C and Stuzel, H. (2009). A New Method for Assesing the Sustainbility of LandUse System (I): Identifying the Relevant Issue. Journal Ecological Economics. 68: 12751287.

17. Wetland International. (1996). Pelingkungan AMDAL Di Lahan Basah (Disampaikan Oleh I.N.N Suryadiputra). Seminar Regional Aplikasi AMDAL Pada Lahan Reklamasi Rawa. Pusat Penelitian Lingkungan. Universitas Lambung Mangkurat. 